\title{
Sendvičová konstelace a well-being člověka: vhled do českého terénu'
}

\author{
Sandwich Generation and Well-being: An Inquiry into Czech Field \\ Michal Šindelář
}

\begin{abstract}
This article introduces the term "sandwich generation" and provides insight into the experiences of the Czech sandwich generation based on quantitative analysis of ISSP 2011-2012 Health and Family and Middle Generation 2004 data. Being a carer is a key component of being 'sandwiched;' therefore, the gender and age of carers, intensity of care and commonality of care provision are researched. Well-being and its relationship to being sandwiched is researched too. Reciprocity of provided support, affective solidarity and work-family stress spill-over are examined as the specifications of well-being. It turns out four percent of Czechs are being sandwiched. These people experience slight work-family stress spill-over. However, providing support to one's own parents is associated with a positive increase in well-being when the support is reciprocal.
\end{abstract}

KEY WORDS Sandwich generation, well-being, care provision

\section{Proč se nyní mluví o sendvičové generaci?}

Pojem sendvičová generace je označením lidí ve věku 40 až 60 let, kteří se nacházejí v průsečíku požadavků několika rolí. Těmi jsou role rodiče podporujícího své děti, role dcery nebo syna pečujících o rodiče své anebo svého partnera a role ekonomicky aktivního člověka. Osoba v konstelaci těchto tří rolí je vystavena konkurujícím si nárokům rolí na čas a peníze, neboli konečné zdroje, které musí dělit (Brody 1981). Synonymem pro sendvičovou generaci je sendvičová konstelace, která klade důraz na souběh rolí.

Důvody, proč se zajímat o sendvičovou konstelaci, rozděluji do dvou argumentů. První argument vychází z demografických změn ve společnosti. V důsledku stárnutí populací vyspělých zemí roste podíl staršího obyvatelstva, a tím se také zvětšuje populace potenciálních př́ijemců péče. Stárnutí populace je doprovázeno menším počtem narozených dětí, což se rovná také menšímu počtu potenciálních poskytovatelů péče. V populaci s menším počtem zplozených potomků na jeden pár roste pravděpodobnost, že dítě bude v budoucnosti pečovat o své rodiče, protože se výrazně zmenšil okruh možných pečovatelů.

Druhý argument se opírá o křrižovatku rolí, které jsou pro lidi v sendvičové konstelaci typické. S demografickými změnami úzce souvisí změna struktury rodiny, která se vertikalizuje. Vertikalizací vyjadřuji „generační výšku“ rodiny, která může běžně pojmout až

Sociálni studia. Katedra sociologie FSS MU, 3/2014. S. 31-49. ISSN 1214-813X.

1 Tento výzkum vznikl s finanční podporou Grantové agentury ČR (projekt č. 13-34958S). 
čtyři generace (Grundy a Henretta 2006). Člověk v sendvičové konstelaci může být zároveň synem/dcerou, rodičem a prarodičem. Vertikalizaci rodiny doplňuje emancipace žen ve společnosti a jejich vstup na trh práce. Ve společnostech, v nichž není dramatický rozdíl mezi podílem ekonomicky aktivních žen a mužů, roste pravděpodobnost dalšího tlaku v sendvičové konstelaci, který zprostředkovává role zaměstnankyně.

Demografický vývoj a změna struktury rodiny však mohou působit i opačně a učinit situaci poskytování péče $\mathrm{v}$ rámci rodiny vzácnější. Snižující se porodnost vyjádřená rostoucím počtem celoživotně bezdětných lidí a na druhé straně rostoucí rozvodovost mohou vyústit do citelného oslabení výskytu rozvětvené vícegenerační rodiny (Možný 2004), a tím ohrozit základní nezbytné podmínky pro poskytování péče starším lidem s omezenou soběstačností. O tom, že bude pribývat starších lidí vyžadujících více či méně péče, nemusíme mít pochybnosti. $\mathrm{V}$ budoucnosti se však můžeme setkat $\mathrm{s}$ tím, že péče $\mathrm{v}$ rámci rodiny (která dnes převládá), bude čím dál vzácnější.

\section{Kdo jsou lidé v sendvičové konstelaci}

Studie k tématu sendvičové generace implicitně předpokládají, že do role pečovatele vstupují lidé během středních let (40-60 let) a že jsou to především ženy, kdo se v sendvičové konstelaci ocitnou. Role rodiče a zaměstnance jsou chápány jako výchozí nastavení, do kterého se přidává „navíc“ ještě role pečovatele o vlastního stárnoucího rodiče. Máme tu tedy dva předpoklady. Za prvé, do role pečovatele vstupuje člověk převážně mezi 40. a 60. rokem života, nebot' se jedná o období, kdy se u jeho rodičů objevuje omezená soběstačnost $\mathrm{v}$ důsledku stárnutí či zdravotních potíží. Za druhé, do role pečovatele vstupují více dcery než synové.

Nyní skrze přehled empirických studií ověřím, nakolik jsou výše popsané předpoklady o sendvičové konstelaci platné. Prozkoumám „profil““ pečovatelů podle jejich pohlaví, věku, vztahu k prŕijemci péče a intenzity poskytované péče.

Jsou to opravdu ženy, koho máme primárně chápat za aktéry sendvičové konstelace? Brodyová mluví především o ,ženách uprostřed“ a odkazuje se na výzkumy, podle kterých je primárním pečovatelem o rodiče dcera anebo snacha či v př́ípadě ovdovělých se pečovatelské úlohy ujímají ženy z nejbližší generace. Prakticky to vypadá tak, že se starší lidé obracejí v případě potřeby pomoci spiše na dcery než na syny a dcery ochotně pomáhají (Brody 1981: 474). Stejné východisko zastává i Millerová, podle které je většina péče o stárnoucí rodiče na bedrech žen v rodině, převážně dcer (Miller 1981: 420).

Zaměřme se nyní pouze na péči o své či partnerovy rodiče z pohledu pohlaví poskytovatele péče. Ve Velké Británii na přelomu 20. století poskytovalo péči svým anebo partnerovým rodičům $9,9 \%$ mužů a $12,8 \%$ žen ve věku 35 až 69 let. Muži nejčastěji poskytovali péči mezi 50. a 54. rokem života (19 \% všech mužů), ženy mezi 45. a 49. rokem života (18\% žen) (Agree et al. 2003: 112). Ve Wisconsinu v 90. letech minulého století byla pečovatelská role s pohlavím svázána trochu více. Nehledě na př́ijemce péče (rodič, partner, dítě, jiný), roli pečovatele ve svých 53 až 54 letech vykonávalo 8,8 \% mužů a $15,1 \%$ žen. Pokud bychom se zaměřili pouze na péči o vlastní či partnerovy rodiče, tak tu vykonávalo 3,3 \% mužů a 6,9 \% žen (Marks 1998: 956). Jiný výzkum, opírající se opět o obyvatele USA, 
se zaměřil pouze na manželské dvojice, v nichž oba - muž i žena - poskytovali alespoň 3 hodiny péče týdně rodiči svému nebo partnerovu. I v situaci zapojení muže i ženy do péče se projevil rozdíl podle pohlaví v rozsahu poskytované péče - muži poskytovali průměrně 5,1 hodiny péče každý týden, zatímco ženy poskytovaly každý týden průměrně 6,8 hodiny péče (Ingersoll-Dayton et al. 2001: 264). K podobným závěrům ohledně spojení pečovatelské role a role ženy dochází na základě dat z ČR Vidovićová a Rabušic. Ženy poskytují pomoc svým starým rodičům intenzivněji než muži (Vidovićová a Rabušic 2003: 23). Výše uvedená zjištění jsou však výsledkem průřezového pohledu na svět, respektive výpovědí respondentů o jejich situaci v momentu dotazování. Wisconsinská data nabízejí i odpověd' na poskytování péče (rodičům, partnerovi, dítěti, jinému př́ijemci) v trvání nejméně 1 měsíc během celého života respondenta. Ke svému 54. roku života 24 \% mužů a 39 \% žen mělo zkušenost s intenzivní rolí pečovatele (Marks 1998).

Z předložených tezí o sendvičové generaci by se mohlo zdát, že péče o stárnoucí rodiče je výhradní starostí jejich potomků, převážně dcer. Obraz péče v rámci rodiny je však rozmanitější. Spillmanová a Pezzinová na reprezentativním vzorku lidí žijících v USA rozkrývají strukturu pečujících o osoby ve věku 65 a více let podle jejich pohlaví, věku a rodinného vztahu k př́ijemci péče. Vzorek omezují pouze na děti nebo druhy př́ijemců péče, kteří podle nich tvoří dvě třetiny všech poskytovatelů péče. Autorky rozlišují dvě úrovně péče, roli hlavního a roli vedlejšího pečujícího. Hlavní pečující je člověk, který je hlavním zdrojem péče pro jejího příjemce. Pokud o člověka pečuje vícero osob, za hlavního pečujícího je určen ten, kdo poskytováním péče tráví nejvíce času (Spillman a Pezzin 2000).

Graf 1 přibližuje věkovou strukturu pečujících podle intenzity péče. Největší počet hlavních pečujících je ve věku 65 až 74 let $(27,3 \%$ ), celé dvě třetiny $(66,1 \%)$ hlavních pečujících jsou ve věku 55 až 84 let. Věkové rozložení vedlejších pečujících je oproti hlavním zešikmené více vlevo. Více než třetina (36 \%) vedlejších pečujících je ve věku 45-54 let

Graf 1: Struktura pečujících o osoby ve věku 65 a více let podle věku a rozsahu péče

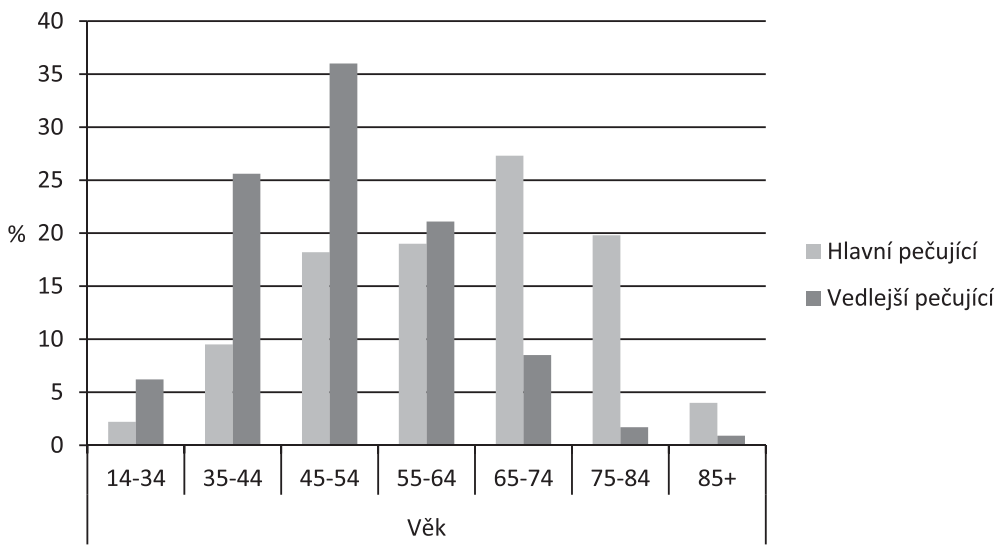

Zdroj: Adaptováno na základě Spillman a Pezzin (2000: 359) 
a spolu s druhou nejpočetnější věkovou kategorií se dostáváme na 61,6 \% vedlejších pečujících ve věku 35 až 54 let. Pro naše úvahy o sendvičové konstelaci je důležité tato zjištění promítnout skrze věkové kategorie typické pro sendvičovou konstelaci. Pro sendvičovou konstelaci je základní podmínkou prrítomnost závislého dítěte, poprrípadě dítěte ve vynořující se dospělosti. Tato podmínka bude nejspíše u člověka přítomna ve věku 35 až 54 let, později je již málo pravděpodobná přítomnost závislých dětí. Graf 1 ukazuje, že v tomto věkovém rozmezí převládá role vedlejšího pečujícího. Jinými slovy, na základě těchto dat lze předpokládat, že člověk ve věku odpovídajícím sendvičové konstelaci bude poskytovat péči stárnoucímu rodiči v součinnosti s dalším člověkem, který bude hlavním pečovatelem. Větší část břemene spojeného s péčí o rodiče bude tedy na bedrech někoho jiného než osob v sendvičové konstelaci.

Č́stečnou odpověd' na otázku, kdo je hlavním pečujícím, dává graf 2, který přináší do diskuse roli manžela či manželky jako pečující osoby. Pokud se dostane partner do role pečovatele osoby starší 65 let, je velmi pravděpodobné, že bude hlavním pečujícím. A naopak, pokud se do situace poskytování péče dostane potomek př́ijemce péče staršího 65 let, bude spíše vedlejším pečujícím. Graf 2 vizuálně poskytuje podporu tvrzení o „,ženách uprostřed“ (Brody 1981); jsou to totiž právě dcery, kdo jsou primárním poskytovatelem péče. Dcery tvoří 55 \% všech vedlejších pečujících a jsou také nejčastěji v roli hlavního pečujícího (35\%).

Graf 2: Struktura pečujících o rodiče své či partnerovy

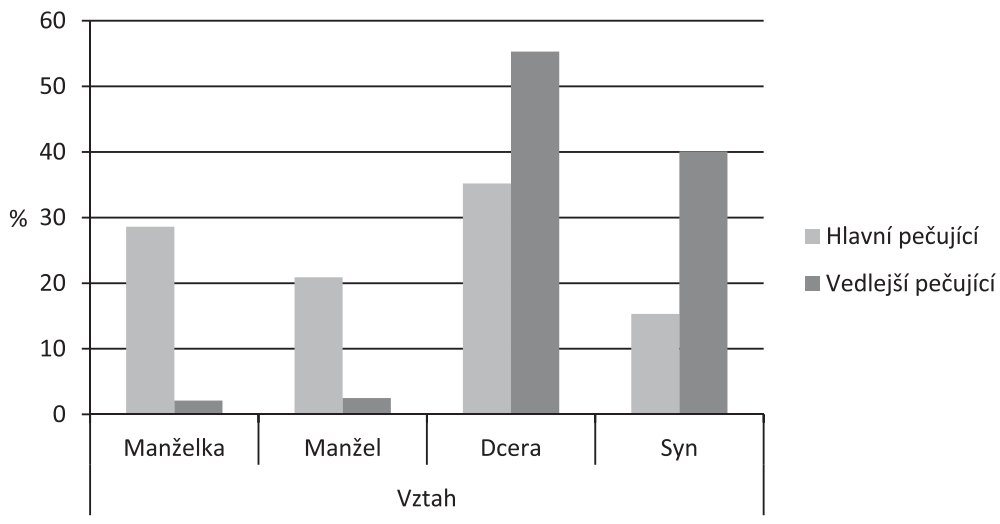

Zdroj: Adaptováno na základě Spillman a Pezzin (2000: 359)

Ačkoliv jsou to dcery, kdo se primárně stará o své rodiče starší 65 let, obraz sendvičové generace se poněkud komplikuje. Pokud vezmeme v úvahu, že celých 70 \% hlavních pečujících je starších 55 let, musíme konstatovat, že větší část objemu rolí hlavních pečujících jde mimo hranice sendvičové generace. Jsou to stále dcery, kdo primárně pečuje, ale z těchto dcer bude jen menší část v sendvičové konstelaci z důvodu dětí na nich závislých. 


\section{Výskył sendvičové konstelace v populaci}

Zatím jsme se zabývali pouze výskytem péče o stárnoucí rodiče vlastní nebo partnerovy, která je konstitutivním prvkem sendvičové konstelace a zdrojem nároků na čas, energii a finance pečujícího. Přidejme do sendviče další prvky, a to roli rodiče, př́tomnost závislých dětí anebo poskytování podpory dětem a roli zaměstnance. Evandrou a Glaser (2002) sledují u kohorty lidí narozených v letech 1936-1940 ve Velké Británii role rodičovské, zaměstnanecké a pečovatelské v závislosti na věku člověka.

Tabulka 1: Rozložení rolí příslušníků kohorty narozených v letech 1936-1940, údaje v \%

\begin{tabular}{|c|c|c|c|c|}
\hline Ženy narozené v & \multicolumn{4}{|c|}{$1936-1940$} \\
\hline Věk & $45-49$ & $50-54$ & $55-59$ & $60-64$ \\
\hline Závislé dítě (17 a méně let) v domácnosti & 34 & 10 & 3 & 1 \\
\hline Péče (o osobu starší, nemocnou nebo s postižením) & 21 & 25 & 21 & 26 \\
\hline Péče 20 a více hodin týdně & 3 & 5 & 7 & 8 \\
\hline Péče, rodičovství a zaměstnání & 10 & 6 & 3 & $<1$ \\
\hline $\begin{array}{l}20 \text { a více hodin péče, rodičovství, zaměstnání } 30 \text { a více } \\
\text { hodin týdně }\end{array}$ & $<1$ & $<1$ & $<1$ & 0 \\
\hline Muži narození v & \multicolumn{4}{|c|}{$1936-1940$} \\
\hline Věk & $45-49$ & $50-54$ & $55-59$ & $60-64$ \\
\hline Závislé dítě (17 a méně let) v domácnosti & 44 & 21 & 9 & 3 \\
\hline Péče (o osobu starší, nemocnou nebo s postižením) & 12 & 17 & 17 & 18 \\
\hline Péče 20 a více hodin týdně & 2 & 3 & 5 & 4 \\
\hline Péče, rodičovství a zaměstnání & 7 & 8 & 3 & 2 \\
\hline $\begin{array}{l}20 \text { a více hodin péče, rodičovství, zaměstnání } 30 \text { a více } \\
\text { hodin týdně }\end{array}$ & 1 & $<1$ & $<1$ & 0 \\
\hline
\end{tabular}

Zdroj: Adaptováno z Evandrou a Glaser (2002)

Tabulka 1 shrnuje rozložení těchto rolí. Role rodiče indikovaná přítomností závislého dítěte ve věku 17 let a méně v domácnosti je s postupujícím věkem vzácnější. Data rozlišují dvě úrovně pečování - méně intenzivní (méně než 20 hodin týdně) a více intenzivní (20 a více hodin týdně). Role méně intenzivního pečovatele je poměrně obvyklá, každá 4 . až 5 . žena a každý 6. muž ve věku 45 až 64 let se v této roli nacházeli. Zajímavější je ovšem souběh rolí rodiče, pečovatele a zaměstnance. Každá 10. žena ve věku 45 až 49 let se v této sendvičové konstelaci nacházela, $\mathrm{s}$ rostoucím věkem však je tato konstelace méně častá (Evandrou a Glaser 2002).

$\mathrm{K}$ dispozici máme informace i o souběhu intenzivnějších rolích, které jsou reprezentovány 20 a více hodinami péče týdně v prrípadě pečovatelské role a 30 a více hodinami práce týdně v př́padě zaměstnanecké role. S rostoucím věkem roste výskyt intenzivní pečovatelské role. Čím je člověk starší, tím je pravděpodobnější, že bude někomu poskytovat 20 a více hodin péče každý týden. Shrňme dosavadní zjištění: $\mathrm{S}$ rostoucím věkem ubývá rodičů se závislými dětmi a zároveň roste podíl lidí poskytujících péči. S rostoucím věkem můžeme 
také očekávat nižší intenzitu participace na trhu práce. Výsledkem by měl být nízký počet lidí nacházejících se v sendvičové konstelaci, tedy v souběhu tří intenzivních rolí pečovatele, rodiče a zaměstnance. To dokládá i tabulka $1-\mathrm{v}$ takto definované sendvičové konstelaci se nachází maximálně každý 100. člověk ve věku 45 až 59 let (Evandrou a Glaser 2002).

Sendvičovou konstelaci bychom tedy měli rozlišovat podle její intenzity, potažmo tlaku, který tato konstelace může vytvářet na konečné zdroje člověka $\mathrm{v}$ jejím středu. Na základě takového rozlišení dostaneme dva poněkud odlišné obrazy o výskytu zkušenosti sendvičové generace ve společnosti. Striktnější definice sendvičové konstelace vede k marginalizaci takové zkušenosti vzhledem $\mathrm{k}$ celé populaci lidí nacházejících se $\mathrm{v}$ př́slušném věku. Evandrou a Glaser (2004) identifikují ve Velké Británii $1 \%$ mužů (ve věku 45 až 64 let) a 3 \% žen (45 až 59 let) v sendvičové konstelaci, ve výše zmiňované studii (2002) pak identifikují maximálně jedno procento mužủ či žen v konstelaci. S rozvolněním definice roste početnost lidí v konstelaci. Künemund (2006) kvalifikuje pro konstelaci všechny, kdo věnují alespoň jednu hodinu měsíčně péči o rodiče, alespoň hodinu měsíčně zaměstnání a mají závislé děti anebo svým dětem pomáhají s vnoučaty. Na německé populaci tím získává $5 \%$ žen a 4 \% mužů ve věku 40-54 let v sendvičové konstelaci.

\section{Vliv sendvičové konstelace na well-being}

Druhým klíčovým aspektem teze o sendvičové generaci je vliv průsečíků rolí na well-being ${ }^{2}$ člověka v něm se nacházejícím. Již Brodyová (1981) upozorňovala na neznámé následky vstupu žen na trh práce $\mathrm{v}$ kombinaci se stále platnou rolí ženy jako pečovatelky. „Ženy uprostřed“ podle ní mohou pracovat na hranici svých možností, aniž by na to společnost brala zřetel. Millerová také argumentuje, že lidé v sendvičové konstelaci zažívají sníženou životní pohodu. To vysvětluje zhoršeným zdravotním stavem rodičů. Zlomená kyčle, mozková mrtvice anebo stařecká demence ovlivňuje fungování celé rodiny, která se musí vyrovnat s novou situací vyžadující péči o stárnoucího rodiče. Rozhovory s lidmi, jejichž rodiče byli čerstvě po mozkové mrtvici, ukazují na řadu starostí, které tyto lidi tíží: jaké má pacient vyhlídky, jakou péči a léčbu bude potřebovat, jak se vyrovnat se změnou statusu pacienta v rodině? (Miller 1981). Lidé v párech ve spíše intenzivnější sendvičové konstelaci popisovali neustálé přepínání mezi požadavky zaměstnání, péče a vlastních dětí jako silný zdroj stresu a přirovnali se k „trojitému sendviči“ (Ingersoll-Dayton et al. 2001: 265).

Nakolik jsou takové zkušenosti typické pro lidi v sendvičové konstelaci? Opravdu všichni lidé v ní zaživají takové snížení životní pohody? Millerová se opírá o prrípadové konference $\mathrm{s}$ rodinami ${ }^{3}$, $\mathrm{v}$ nichž starší rodič utrpěl mozkovou příhodu. Je třeba rozlišovat

2 Termín well-being označuje v tomto textu obecnou kvalitu života, která bude dále v empirické části upřesněna na konkrétní indikátory. Termín well-being je běžně užívaným označením pro závislou proměnnou v kontextu výzkumů sendvičové generace v anglickém jazyce. České ekvivalenty by mohly být kvalita života, životní pohoda či dokonce dobré bydlo, v tomto textu se však rozhoduji termín nepřekládat a pracovat s jeho původní podobou.

3 Př́ípadová konference je typ poskytování pomoci či intervence, kdy př́ijemcem pomoci není izolovaný jednotlivec, ale pomoc je namířena na všechny osoby krizovou situací dotčené. 
mezi krizovou situací a sendvičovou konstelací. V krizové situaci (mozková př́ihoda anebo zlomenina kyčle staršího rodiče) se musí člověk vyrovnat s náhlou situací ohrožujíć život blízkého člověka a navíc vyžadující množství péče, kterou je třeba nejprve zařídit a osvojit si ji. To je relevantní zdroj napětí a stresu, na tuto situaci se však člověk může adaptovat. Teze o sendvičové konstelaci však mluví o konkurujících si požadavcích tří rolí. Ani u ní však není vliv na well-being zcela jednoznačný. Künemund (2006: 13) upozorňuje, že mnoho studií vlivu sendvičové konstelace na well-being pracuje především s př́pady lidí ve velmi tíživých situacích, a že tak není jasné, zda konstelace má opravdu negativní vliv na well-being a životní spokojenost.

Opřeme se nyní o studie pracující s většími vzorky lidí v sendvičové konstelaci. Na přelomu 80. a 90. let v USA podle reprezentativního vzorku neměla př́tomnost pečovatelských povinností vůči rodičům a dětem vliv na kvalitu manželství, psychologický well-being, finanční zdroje a spokojenost s trávením volného času (Loomis a Booth 1995: 139). Jiná reprezentativní data z USA říkají, že počet hodin věnovaných péči o rodiče neměl vliv na well-being pečujících žen, avšak na well-being pečujících mužů ano (Marks 1998: 954). $\mathrm{V}$ datech reprezentujících německou populaci ve středních letech nebyl nalezen vztah mezi sendvičovou konstelací na jedné straně a spokojeností se životem a negativními afekty na straně druhé (Künemund 2006). Žádný vliv konstelace na zdraví člověka nebyl potvrzen ani daty reprezentujícími seniory Velké Británie (Evandrou a Glaser 2004). Studie založené na reprezentativních vzorcích, at' už celé populace či pouze populace osob v sendvičové konstelaci, poukazují na absenci negativního vlivu konstelace na well-being člověka.

Tato zjištění jsou ve zjevném rozporu se základní tezí o sendvičové konstelaci a negativním dopadu konkurujících si rolových požadavků na životní pohodu člověka. Pokud by sendvičová konstelace neměla vliv na well-being, těžko bychom si zdůvodňovali, proč se jí vůbec zabývat. Tento rozpor je třeba vyřešit, a to hlubším porozuměním vztahu mezi konstelací a well-beingem. Studie, které předpokládaný negativní dopad na well-being nenacházely, obvykle pracujís takovou operacionalizací well-beingu, která ve své povaze specifický dopad sendvičové konstelace není schopna zachytit. Obvykle se jedná o obecné škály měříí celkovou spokojenost se životem. Používání těchto škál kritizují Bliesznerová a Mancini (1989) a dodávají, že je třeba se zaměřit na jednotlivé dimenze životní spokojenosti, například na spokojenost s mezilidskými vztahy. Předpokládaný dopad na well-being je tedy třeba upřesnit a dostatečně teoreticky podložit.

Obrázek 1: Schéma trojúhelníkové konstelace

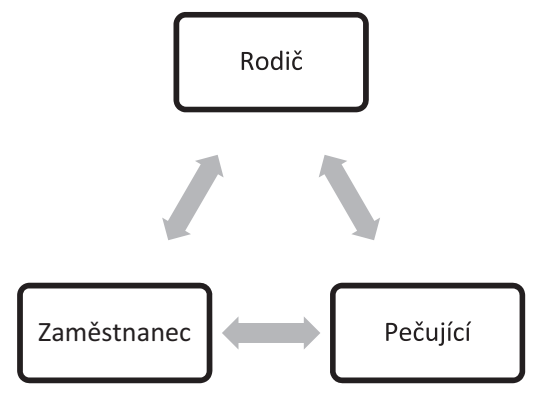


Intenzivní trojúhelníková konstelace role rodičovské, zaměstnanecké a pečovatelské může přinášet jeden hlavní zdroj nepohodlí člověka. Tím je konflikt mezi rolí zaměstnance a rolí člena rodiny se závazky vůči rodině. Konflikt mezi zaměstnáním a rodinou považujme za první specifikaci dopadů sendvičové konstelace na well-being člověka. Pro toto upřesnění nacházíme i empirickou podporu. Marks (1998) demonstruje, že lidem současně v rolích zaměstnance a pečovatele zasahuje pracovní stres do rodinných záležitostí a rodinný stres do pracovních záležitostí, zatímco lidé zaměstnaní, avšak nepečující, toto přelévání stresu mezi rodinou a prací zažívají méně. Stejným směrem ukazují i data z ČR od zaměstnaných žen ve věku 45 až 65 let zkoumající vliv pečovatelské role na spokojenost se skloubením soukromého a pracovního života. Nejvíce spokojeny jsou ženy nepečující (75\% spokojených), následovány ženami pečujícími bud' o rodiče, anebo o děti $(50 \%)$, a nejméně spokojených je mezi zaměstnanými ženami, které pečují zároveň o děti a rodiče $(30 \%)$ (Gender Studies, o.p.s. 2013). Formuluji následující hypotézu:

H1: Sendvičová konstelace bude asociována s vyšším nesouladem mezi pracovní a soukromou sférou.

Další zdroj nepohodlí, kterým se budu zabývat, je spojen se sendvičovou konstelací skrze interakce mezi osobou v sendvičové konstelaci a rodiči prrijímajícími péči. Tyto interakce ovlivňují celkové množství zdrojů, které má člověk v sendvičové konstelaci k dispozici a kterých může případně být nedostatek. Interakce rozlišuji na dvou úrovních. Za prvé, reciprocita pomoci mezi osobou v konstelaci a jejími rodiči, která signalizuje, že člověk svůj čas, energii a peníze nejen dává, ale od jejích př́ijemců také dostává. Druhou úrovní je míra afektuální solidarity, která indikuje mezilidskou blízkost a vřelost mezi člověkem a jeho rodiči.

Reciprocita v rodině zastupuje takové vzorce chování, pro které je typická častá vzájemná podpora. Míru reciprocity můžeme chápat i jako indikátor well-beingu celé rodiny (Blieszner a Mancini 1989). Pokud se však člověk ocitne v sendvičové konstelaci, hodnota reciprocity může být vychýlena a to se promítne do kvality vztahu, typicky mezi pečující osobou a př́jemcem péče. Nerovnováha mezi „,vydanými“ a „přijatými“ zdroji může vytvořit nechtěný pocit závazku, a tak negativně ovlivnit mezigenerační vztahy (Whitbeck et al. 1994). Vychýlenou reciprocitu vzájemné pomoci můžeme uchopit i jako pomoc obnášející čas, energii a peníze člověka, kterou vydává, aniž by přijímal relevantní množství pomoci nazpět. Formuluji hypotézu:

H2: Snižující se míra reciprocity bude asociována s negativním hodnocením vztahu $s$ rodiči.

Afektuální solidarita reprezentuje druhou úroveň kvality vztahu. Pod afektuální solidaritou si můžeme představit jednoduše blízkost dvou osob (Szydlik 2008), kterou lze charakterizovat skrze náklonnost, vřelost, porozumění, důvěru a míru vnímané reciprocity této blízkosti (Bengtson a Roberts 1991). Na důležitost afektuální solidarity pro člověka v sendvičové konstelaci poukazovala již Millerová. Vztah se stárnoucím rodičem, který byl zakoušen jako odmítající, nemilující a nepečující, může komplikovat dospělému dítěti vyrovnání se s nově nabytou rolí pečovatele o toho samého rodiče (Miller 1981: 421). Vztah s odmítajícím rodičem snižuje afektuální solidaritu, zvyšuje napětí ve vztahu a snižuje pocit’ovanou starost o well-being rodiče a ve výsledku také snižuje pravděpodobnost poskytnutí péče v př́ípadě potřeby (Whitbeck et al. 1994). Avšak i děti, které ke svým rodičům necítí blízkost, jsou stále 
schopny poskytnout svým rodičům péči. Tato péče je však hodnocena jako více stresující než v př́ípadě silnější afektuální solidarity (Horowitz a Shindelman in Blieszner a Mancini 1989). Silnější afektuální solidarita indikovaná příjmem emoční podpory pečujícím predikuje lepší hodnocení kvality vztahu mezi pečujícím dítětem a opečovávaným rodičem a také předpovídá lepší vnímání pečovatelského výkonu ze strany dítěte (Ingersoll-Dayton et al. 2001). Na základě těchto poznatků formuluji hypotézu:

H3: Nizká afektuální solidarita bude asociována s negativním hodnocením kvality vztahu s príjemcem péče.

Kde vztah mezi sendvičovou konstelací a well-beingem neočekávám, je hodnocení well-beingu na základě globálního indikátoru, např. tvrzením o celkové životní spokojenosti nebo pocitu štěstí. Formuluji následující hypotézu:

H4: Sendvičová konstelace nemá vliv na celkový well-being člověka.

\section{Výzkumná část}

Popis datových souborů a proměnných

ISSP 2011-2012 Rodina a zdraví

Data pro toto výběrové šetrení byla sbírána $\mathrm{v}$ únoru a březnu 2012. Jedná se o prưrezový výzkum, populaci výzkumných jednotek tvoří obyvatelé ČR starší 18 let. Náhodným výběrem byla sebrána data od 1804 respondentů. Při analýze dat byl soubor vážen podle pohlaví, věku, vzdělání, ekonomického postavení, kraje a velikosti místa bydliště. Míra návratnosti byla $56 \%$.

ISSP data obsahují informace o př́tomnosti závislých dětí v domácnosti respondenta, jeho ekonomické aktivitě, poskytování péče členům rodiny, kteří jsou starší, nemocní či nemohoucí, a o přítomnosti konfliktu mezi pracovní a rodinnou sférou. Na datech budou ověřovány hypotézy $\mathrm{H} 1 \mathrm{a} \mathrm{H} 4$.

\section{Střední generace 2004}

Data pro průřezový výzkum byla sbírána v roce 2004. Kvótním výběrem byly shromážděny odpovědi od 1059 respondentů. Jako výzkumná jednotka pro tento výzkum se kvalifikovali lidé na území ČR, kteř́ byli ve věku 45-59 let, byli ekonomicky aktivní, vychovali alespoň jedno dítě a $v$ době sběru dat $s$ nimi nežilo žádné dítě ve společné domácnosti.

Vzhledem k povaze výběru vylučující sdílení domácnosti se závislým dítětem jsem se při analýze těchto dat zaměřil na vztah s rodiči respondenta a podporu mezi respondentem a jeho rodiči. Na těchto datech budou ověřovány hypotézy H2 a H3. Do analýzy vstoupili pouze respondenti, kteří měli alespoň jednoho rodiče v době dotazování naživu $(\mathrm{N}=603)$.

Oba datové soubory jsou prưřrezovými daty, nemůžeme tedy na jejich základě tvořit závěry o kauzalitě, $\mathrm{k}$ tomu bychom potřebovali panelová data. Získané poznatky o asociacích mezi zkoumanými proměnnými nám mohou být pouze vodítkem o povaze pečovatelské situace, nikoliv poznatky s konečnou platností. 
Použité proměnné

ISSP 201 1-2012 Rodina a zdraví

Sendvičovou konstelaci operacionalizuji skrze následující proměnné:

1. Přítomnost závislých dětí ve věku 17 let a méně v domácnosti respondenta, indikovaná odpovědí na otázku (proměnná S26SN, resp. S25SN), Kolik je z toho závislých dětí ve věku 0-6 (resp. 7-17) let, které s Vámi žijí ve společné domácnosti?““

2. Ekonomická aktivita respondenta indikovaná odpovědí „Jsem v současnosti výdělečně činný(á)“ na otázku (proměnná S4) „Jste v současnosti výdělečně činný/á, byl/a jste v minulosti výdělečně činný/á, nebo jste nikdy nebyl(a) výdělečně činný/á?““

3. Poskytování péče, indikované odpovědí „Ano“ otázku (proměnná S37) „Poskytujete Vy osobně pravidelnou péči členům Vaší rodiny, kteří jsou starší, nemocní či nemohoucí?"“

K vytvoření indikátoru pro nesoulad mezi pracovní a soukromou sférou pro testování H1 jsem použil proměnnou B23 „Jak často se Vám během posledních tří měsíců stala každá z těchto věcí?"“ a čtyři její varianty:

B23A. Přišel(a) jsem z práce domů tak unavený(á), že jsem nebyl(a) schopen(a) doma udělat věci, které byly potřeba.

B23B. Kvưli množství času, které jsem strávil(a) v zaměstnání, pro mě bylo obtížné plnit rodinné povinnosti.

B23C. Kvůli práci v domácnosti, kterou jsem musel(a) udělat, jsem přišel(a) do zaměstnání tak unavený(á), že jsem nebyl(a) schopen(a) dobře pracovat.

B23D. Zjistil(a) jsem, že pro rodinné povinnosti je pro mne obtížné se soustředit na práci.

Tyto položky navzájem úzce souvisely. Faktorovou analýzou jsem získal jeden faktor vysvětlující $61 \%$ rozptylu v datech, Cronbachovo $\alpha$ z těchto položek nabylo hodnoty 0,77 . Vzhledem k ordinální povaze těchto proměnných jsem vytvořil sumační index, do kterého jsem načítal odpovědi „Několikrát za týden“ a „Několikrát za měsíc“ (zbylé možné odpovědi byly „Jednou nebo dvakrát“, „Nikdy“). Pro přehlednější interpretaci jsem index rekódoval do tří kategorií:

1. Žádná s těchto situací se respondentovi nepřihodila (57\%)

2. Respondentovi se přihodila 1 nebo 2 situace $(35 \%)$

3. Respondentovi se prrihodily 3 nebo 4 situace $(8 \%)$

$(\mathrm{N}=1096$, pouze ekonomicky aktivní respondenti)

Celkový well-being člověka indikuje proměnná B24, zjišt'ující pocit štěstí v životě respondenta. Sedmistupňovou ordinální stupnici jsem rekódoval na základě distribučního principu do tří kategorií obsahujících odpovědi:

1. Zcela št’astný; velmi št'astný (31\%)

2. Docela št'astný (46\%)

3. Ani št’astný, ani nešt’astný; Docela/Velmi/Zcela nešt'astný (23\%)

$(\mathrm{N}=1787)$ 


\section{Strední generace 2004}

Péče o rodiče, respektive podpora rodičům, je indikována odpovědí „Vždy, je-li to třeba“ (ostatní možnosti „Občas“, „Jen výjimečně“, „Vůbec ne“) otázku (proměnná 80) „Jak často poskytujete svým rodičům následující podporu?" a šest variant této proměnné:

$80 \_2$ Pomoc s běžným chodem domácnosti

80_3 Pomoc při větších domácích pracích (velký úklid, domácí hospodářství apod.)

80_4 Nákupy, doprovod k lékaři apod.

$80 \_$Pomoc v péči o osobní hygienu

$80 \_$Péče v době nemoci

80_7 Finanční podpora

Z těchto položek jsem vytvořil součtový index, do kterého byly načítány pouze odpovědi „Vždy, je-li to třeba“. Index jsem dále rekódoval do dichotomické proměnné s kategoriemi:

1. Respondent neposkytuje rodičům žádnou podporu anebo jeden druh podpory $(55 \%)$

2. Respondent poskytuje rodičům 2 až 6 druhů podpory (45\%).

$(\mathrm{N}=603$, pouze respondenti s žijícím rodičem)

Nedostatkem tohoto indikátoru je absence definice časového rámce či vyjádření četnosti podpory rodičům. Význam odpovědí „Občas“ anebo „Vždy, je-li to třeba“ se může napříč respondenty významně lišit.

Na reciprocitu pomoci mezi respondentem a jeho rodiči jsem usuzoval na základě kombinace indikátoru poskytování péče rodičům a tří variant proměnné $\mathrm{R} 89$, indikující př́ijem podpory od rodičů: „Poskytují Vám Vaši rodiče obdobnou pomoc?“

R89B Pomoc při větších domácích pracích

R89C Péče $v$ době nemoci

R89D Finanční podpora

Z těchto proměnných jsem vytvořil sumační index načítající odpovědi „Ano“, který jsem následně rekódoval do proměnné se třemi kategoriemi:

1. Žádná pomoc od rodičů $(70 \%)$

2. Jeden druh pomoci od rodičů $(20 \%)$

3. Dva až tři druhy pomoci od rodičů $(11 \%)$

$(\mathrm{N}=603)$

Afektuální solidarita, konceptualizovaná jako mezilidská blízkost, byla operacionalizována jako odpověd’ „Vždy, je-li to třeba“ otázku (proměnná 80 1) zjišstující, zda respondent poskytuje svým rodičům podporu formou vzájemných diskusí a citové opory. Proměnná byla dichotomizována do této podoby:

1. Vždy, je-li to třeba (53\%)

2. Občas, jen výjimečně, vůbec ne (47\%)

$(\mathrm{N}=603)$ 
Kvalitu vztahu jako specifický indikátor well-beingu jsem operacionalizoval jako hodnocení současného vztahu s rodiči respondentem, proměnná S9A. Proměnná byla dichotomizována:

1. Velmi dobré vztahy $(42 \%)$

2. Jiné (Spíše dobré, spíše špatné, velmi špatné) (58 \%)

$(\mathrm{N}=603)$

\section{Výsledky}

Výskył sendvičové konstelace v ČR

Tabulka 2 shrnuje rozložení poskytování péče, př́tomnosti závislého dítěte $\mathrm{v}$ domácnosti ve věku 17 let a méně a ekonomickou aktivitu respondentů vzhledem $\mathrm{k}$ jejich věku. Nejprve je popsáno rozložení jednotlivých vlastností zvlášt', následně ve vzájemných kombinacích a poslední řádek zastupuje výskyt sendvičové konstelace.

Tabulka 2: Poskytování péče, ekonomická aktivita a přítomnost závislého dítěte v domácnosti podle věku respondenta

\begin{tabular}{|c|c|c|c|c|c|c|c|c|c|}
\hline \multicolumn{10}{|c|}{ Věkové kategorie } \\
\hline & & $\begin{array}{c}18-29 \\
\text { let }\end{array}$ & $\begin{array}{c}30-39 \\
\text { let }\end{array}$ & $\begin{array}{c}\text { 40-49 } \\
\text { let }\end{array}$ & $\begin{array}{c}50-59 \\
\text { let }\end{array}$ & $\begin{array}{c}60-69 \\
\text { let }\end{array}$ & $\begin{array}{c}70 \text { a více } \\
\text { let }\end{array}$ & Celkem & N \\
\hline \multirow{2}{*}{$\begin{array}{l}\text { Podíl } \\
\text { pečujících }\end{array}$} & Počet & 35 & 72 & 62 & 79 & 57 & 30 & 335 & 1803 \\
\hline & $\%$ & $10,0 \%$ & $19,5 \%$ & $21,3 \%$ & $26,8 \%$ & $21,2 \%$ & $13,2 \%$ & $18,6 \%$ & \\
\hline \multirow{2}{*}{$\begin{array}{l}\text { Závislé dítě } \\
\text { v domácnosti }\end{array}$} & Počet & 105 & 231 & 136 & 28 & 10 & 8 & 518 & 1785 \\
\hline & $\%$ & $30,1 \%$ & $63,6 \%$ & $47,4 \%$ & $9,6 \%$ & $3,7 \%$ & $3,6 \%$ & $29,0 \%$ & \\
\hline \multirow{2}{*}{$\begin{array}{l}\text { Ekonomická } \\
\text { aktivita }\end{array}$} & Počet & 165 & 313 & 258 & 227 & 39 & 2 & 1004 & 1805 \\
\hline & $\%$ & $46,9 \%$ & $84,6 \%$ & $88,7 \%$ & $76,7 \%$ & $14,5 \%$ & $0,9 \%$ & $55,6 \%$ & \\
\hline \multirow[t]{2}{*}{ Péče a práce } & Počet & 16 & 58 & 56 & 60 & 9 & 0 & 199 & 1803 \\
\hline & $\%$ & $0,9 \%$ & $3,2 \%$ & $3,1 \%$ & $3,3 \%$ & $0,5 \%$ & $0,0 \%$ & $11,0 \%$ & \\
\hline \multirow{2}{*}{$\begin{array}{l}\text { Péče a závislé } \\
\text { dítě }\end{array}$} & Počet & 4 & 52 & 34 & 11 & 7 & 2 & 110 & 1785 \\
\hline & $\%$ & $0,2 \%$ & $2,9 \%$ & $1,9 \%$ & $0,6 \%$ & $0,4 \%$ & $0,1 \%$ & $6,2 \%$ & \\
\hline \multirow{2}{*}{$\begin{array}{l}\text { Péče, dítě } \\
\text { a práce }\end{array}$} & Počet & 1 & 39 & 29 & 8 & 1 & 0 & 78 & 1786 \\
\hline & $\%$ & $0,1 \%$ & $2,2 \%$ & $1,6 \%$ & $0,4 \%$ & $0,1 \%$ & $0,0 \%$ & $4,4 \%$ & \\
\hline
\end{tabular}

Zdroj: ISSP 2011-2012 Rodina a zdraví

V celém souboru je 4,4 \% respondentů v sendvičové konstelaci, v populaci můžeme očekávat výskyt konstelace v intervalu 3,3 až 5,3 \% (při 95\% i.s.). Většina lidí v sendvičové konstelaci se nachází ve věku 30 až 49 let, což je do velké míry způsobeno operacionalizací sendvičové konstelace založené na př́tomnosti závislých dětí ve věku 17 a méně let v domácnosti. Pokud bychom toto kritérium posunuli na vyšší věkovou hranici (což data bohužel 
nedovolují), výrazně by vzrostl podíl lidí v sendvičové konstelaci i ve věku 50 až 59 let, nebot' právě $\mathrm{v}$ této skupině každý čtvrtý respondent deklaroval péči o člena rodiny a zároveň trri čtvrtiny respondentů jsou stále ekonomicky aktivní. Uvedená $4 \%$ respondentů v sendvičové konstelaci představují zástupce mírné definice konstelace. Péče o člena rodiny nepodléhá žádnému kritériu intenzity, a nutně tak bude zahrnovat poskytování sice pravidelné péče, ale menšího časového rozsahu.

Při pohledu na různé kombinace třech klíčových proměnných můžeme postřehnout, že sendvičová konstelace je poměrně vzácnou. Nejčastějším souběhem rolí je práce a péče (11\% respondentů), následuje souběh péče a přítomnosti závislého dítěte $(6 \%)$ a sendvičová konstelace tří rolí je nejméně častou (4\%). V sendvičové konstelaci se mírně častěji nacházejí ženy $(58 \%)$ než muži $(42 \%)$.

\section{Sendvičová konstelace a konflikt mezi pracovní a soukromou sférou}

Ověřujeme hypotézu H1 předpokládající, že sendvičová konstelace zvyšuje nesoulad mezi pracovní a soukromou sférou. Do analýzy vstoupili pouze ekonomicky aktivní respondenti.

Tabulka 3: Konflikt mezi pracovní a soukromou sférou podle sendvičové konstelace

\begin{tabular}{|c|c|c|c|c|c|}
\hline & & & \multicolumn{2}{|c|}{ Sendvičová konstelace } & \multirow[t]{2}{*}{ Celkem } \\
\hline & & & $\mathrm{Ne}$ & Ano & \\
\hline \multirow{8}{*}{$\begin{array}{l}\text { Konflikt mezi } \\
\text { pracovní } \\
\text { a soukromou } \\
\text { sférou }\end{array}$} & \multirow{2}{*}{$\begin{array}{l}\text { Žádná z těchto situací se } \\
\text { respondentovi neprihodila }\end{array}$} & Počet & 594 & 34 & 628 \\
\hline & & $\%$ & $58,3 \%$ & $43,6 \%$ & $57,3 \%$ \\
\hline & \multirow{2}{*}{$\begin{array}{l}\text { Respondentovi se prihodila } 1 \\
\text { nebo } 2 \text { situace }\end{array}$} & Počet & 347 & 38 & 385 \\
\hline & & $\%$ & $34,1 \%$ & $48,7 \%$ & $35,1 \%$ \\
\hline & \multirow{2}{*}{$\begin{array}{l}\text { Respondentovi se prihodily } 3 \\
\text { nebo } 4 \text { situace }\end{array}$} & Počet & 77 & 6 & 83 \\
\hline & & $\%$ & $7,6 \%$ & $7,7 \%$ & $7,6 \%$ \\
\hline & \multirow[t]{2}{*}{ Celkem } & Počet & 1018 & 78 & 1096 \\
\hline & & $\%$ & $100,0 \%$ & $100,0 \%$ & $100,0 \%$ \\
\hline
\end{tabular}

Zdroj: ISSP 2011-2012 Rodina a zdraví

Tabulka 3 poukazuje na mírné rozdíly mezi lidmi v sendvičové konstelaci a ostatními. Konflikt mezi pracovní a soukromou sférou je nepřítomný u $44 \%$ respondentů v sendvičové konstelaci, u lidí mimo tuto konstelaci se však jedná o $58 \%$. Tento $14 \%$ rozdíl se bezezbytku přelévá do prostřední kategorie konfliktu mezi pracovní a soukromou sférou ve „prospěch“ lidí v sendvičové konstelaci, kteří zažívají vy̌šśi nesoulad mezi pracovní a soukromou sférou než lidé mimo konstelaci. Rozdíly v četnostech jsou statisticky signifikantní, $\mathrm{X}^{2}(2, N=1096)$ $=7,17, p=.01$, přijímáme hypotézu H1 o sendvičové konstelaci zvyšující nesoulad mezi pracovní a soukromou sférou. 
Vliv sendvičové konstelace na celkový well-being člověka

Ačkoliv tabulka 4 naznačuje, že se lidé v sendvičové konstelaci mohou cítit št’astnější než lidé mimo ni, rozdíly $\mathrm{v}$ rozložení četností v tabulce nejsou statisticky signifikantní, $\mathrm{X}^{2}(2, N=1788)=3,48, p=.18$. Přijímáme hypotézu H4 o absenci vlivu sendvičové konstelace na celkový well-being člověka.

Tabulka 4: Vliv sendvičové konstelace na celkový well-being člověka

\begin{tabular}{|l|l|c|c|c|}
\hline \multirow{2}{*}{\multicolumn{2}{|c|}{}} & \multicolumn{2}{c|}{ Sendvičová konstelace } & \multirow{2}{*}{ Celkem } \\
\cline { 3 - 5 } \multicolumn{2}{|c|}{} & Ne & Ano & \\
\hline \multirow{2}{*}{ Zcela štastný; velmi štastný } & Počet & 523 & 30 & 553 \\
\cline { 2 - 5 } & $\%$ & $30,6 \%$ & $38,5 \%$ & $30,9 \%$ \\
\hline \multirow{2}{*}{ Docela štastný } & Počet & 792 & 36 & 828 \\
\cline { 2 - 5 } & $\%$ & $46,3 \%$ & $46,2 \%$ & $46,3 \%$ \\
\hline \multirow{2}{*}{$\begin{array}{l}\text { Ani šfastný, ani neštastný; Docela/ } \\
\text { Velmi/Zcela nešfastný }\end{array}$} & Počet & 395 & 12 & 407 \\
\cline { 2 - 5 } & $\%$ & $23,1 \%$ & $15,4 \%$ & $22,8 \%$ \\
\hline \multirow{2}{*}{\begin{tabular}{l} 
Celkem \\
\cline { 2 - 5 }
\end{tabular}} & Počet & 1710 & 78 & 1788 \\
\cline { 2 - 5 } & $\%$ & $100,0 \%$ & $100,0 \%$ & $100,0 \%$ \\
\hline
\end{tabular}

Zdroj: ISSP 2011-2012 Rodina a zdraví

Vliv reciprocity péče na kvalitu vztahu

Hypotézu H2 předpokládající, že se snižující se mírou reciprocity podpory mezi rodiči a jejich dospělými dětmi se bude snižovat kvalita vztahu s rodiči, budeme prozkoumávat tabulkou 5 .

V situaci s nejnižší reciprocitou vzájemné podpory (žádná pomoc od rodičů a zároveň téměř žádná podpora rodičům) nejméně lidí hodnotí vztah s rodiči jako velmi dobrý (30,5\%). Naopak nejvíce lidí hodnotí vztah s rodiči jako velmi dobrý v situaci intenzivní reciprocity (70 \%). Nacházím v datech podporu pro hypotézu H2, v situaci poskytování podpory rodičům roste pozitivní hodnocení vztahu s rodiči s tím, jak roste množství podpory od rodičů.

\section{Vliv afektuální solidarity na kvalitu vztahu s rodiči}

Třetí hypotézou předpokládám, že pokud respondent $\mathrm{k}$ rodiči necítí blízkost a bude nucen o rodiče pečovat, bude to pro něj znamenat stresující situaci, která se negativně promítne do vztahu s rodičem. Pro prozkoumání tohoto předpokladu je stěžejní horní polovina tabulky 6 indikující sníženou afektuální solidaritu, respektive blízkost mezi respondentem a jeho rodičem. Pokud hypotéza platí, respondenti s nízkou afektuální solidaritou směrem k rodičům poskytující péči rodičům budou hodnotit vztah méně pozitivně než respondenti se stejně sníženou afektuální solidaritou, kteří svým rodičům péči neposkytují. Je tomu však přesně naopak, jsou to právě pečující respondenti, kteří častěji hodnotí vztah s rodičem jako velmi dobrý (38\%) než nepečující respondenti (20\%). 
Tabulka 5: Vliv reciprocity péče na kvalitu vztahu s rodiči

\begin{tabular}{|c|c|c|c|c|c|}
\hline & & & \multicolumn{2}{|c|}{ Kvalita vztahu s rodiči } & \multirow[t]{2}{*}{ Celkem } \\
\hline & & & Velmi dobrý & Jiný & \\
\hline \multirow{4}{*}{$\begin{array}{l}\text { Žádná pomoc } \\
\text { od rodičů }\end{array}$} & \multirow{2}{*}{$\begin{array}{l}1 \text { druh podpory rodičům } \\
\text { anebo žádná podpora }\end{array}$} & Počet & 76 & 173 & 249 \\
\hline & & $\%$ & $30,5 \%$ & $69,5 \%$ & $100,0 \%$ \\
\hline & \multirow{2}{*}{$\begin{array}{l}2 \text { až } 6 \text { druhů podpory } \\
\text { rodičům }\end{array}$} & Počet & 81 & 91 & 172 \\
\hline & & $\%$ & $47,1 \%$ & $52,9 \%$ & $100,0 \%$ \\
\hline \multirow{4}{*}{$\begin{array}{l}\text { Jeden druh } \\
\text { pomoci } \\
\text { od rodičů }\end{array}$} & \multirow{2}{*}{$\begin{array}{l}1 \text { druh podpory rodičům } \\
\text { anebo žádná podpora }\end{array}$} & Počet & 22 & 29 & 51 \\
\hline & & $\%$ & $43,1 \%$ & $56,9 \%$ & $100,0 \%$ \\
\hline & \multirow{2}{*}{$\begin{array}{l}2 \text { až } 6 \text { druhů podpory } \\
\text { rodičưm }\end{array}$} & Počet & 38 & 29 & 67 \\
\hline & & $\%$ & $56,7 \%$ & $43,3 \%$ & $100,0 \%$ \\
\hline \multirow{4}{*}{$\begin{array}{l}\text { Dva až tři } \\
\text { druhy pomoci } \\
\text { od rodičů }\end{array}$} & \multirow{2}{*}{$\begin{array}{l}1 \text { druh podpory rodičům } \\
\text { anebo žádná podpora }\end{array}$} & Počet & 13 & 18 & 31 \\
\hline & & $\%$ & $41,9 \%$ & $58,1 \%$ & $100,0 \%$ \\
\hline & \multirow{2}{*}{$\begin{array}{l}2 \text { až } 6 \text { druhů podpory } \\
\text { rodičům }\end{array}$} & Počet & 23 & 10 & 33 \\
\hline & & $\%$ & $69,7 \%$ & $30,3 \%$ & $100,0 \%$ \\
\hline
\end{tabular}

Zdroj: Střední generace 2004. N = 603 (pouze respondenti s žijícím rodičem)

Tabulka 6: Vliv afektuální solidarity na kvalitu vztahu s rodiči

\begin{tabular}{|c|c|c|c|c|c|c|}
\hline & & & & Kvalita vzt & s rodiči & \\
\hline & & & & Velmi dobrý & Jiný & Celkem \\
\hline Vzájemné & Občas, jen & 1 druh podpory & Počet & 41 & 164 & 205 \\
\hline citová opora & vübec ne & žádná podpora & $\%$ & $20,0 \%$ & $80,0 \%$ & $100,0 \%$ \\
\hline & & 2 až 6 druhů & Počet & 31 & 50 & 81 \\
\hline & & & $\%$ & $38,3 \%$ & $61,7 \%$ & $100,0 \%$ \\
\hline & Vždy, je-li & 1 druh podpory & Počet & 70 & 56 & 126 \\
\hline & & žádná podpora & $\%$ & $55,6 \%$ & $44,4 \%$ & $100,0 \%$ \\
\hline & & 2 až 6 druhů & Počet & 111 & 80 & 191 \\
\hline & & & $\%$ & $58,1 \%$ & $41,9 \%$ & $100,0 \%$ \\
\hline
\end{tabular}

Zdroj: Střední generace 2004. N = 603 (pouze respondenti s žijícím rodičem)

\section{Závěr a diskuse}

Jak častá je sendvičová konstelace v ČR a jakých charakteristik jsou lidé, kteří se v konstelaci nachází? Díky datům ISSP 2011-2012 mohu říct, že sendvičová konstelace je spíše vzácná a nachází se $\mathrm{v}$ ní kolem $4 \%$ respondentů. Lidé v konstelaci se př́liš neliší podle pohlaví (58 \% žen, 42 \% mužů) a většina $\mathrm{z}$ nich je ve věku 30 až 49 let. Tato čísla si však zaslouží komentár. 
Pracuji s mírnou definicí sendvičové konstelace, která nestanovuje minimální počet hodin péče anebo ekonomické aktivity. Č́st ze $4 \%$ respondentů v konstelaci se bude nutně nacházet v konstelaci nízké intenzity, kdy rolové požadavky budou nižší intenzity a nebude docházet ke konfliktu mezi nimi při nárokování zdrojů člověka v konstelaci. Kdybych aplikoval další kritéria konstelace, např. alespoň 20 hodin ekonomické aktivity týdně a/nebo alespoň 10 hodin péče týdně, podíl lidí v sendvičové konstelaci by se dále zredukoval na méně než $4 \%$. Absence indikátoru pro intenzitu role pečovatele mi nedovoluje rozlišit mezi rolemi hlavního a vedlejšího pečovatele. Nemohu tedy ověřit, zda většina lidí v konstelaci v ČR, kteří jsou ve věku 30 až 49 let, není ve vztahu k rodičům vedlejšími pečovateli, jako je tomu ve stejné věkové skupině v USA (viz graf 1 dle Spillmana a Pezzina [2000]).

Dalším limitem dat o sendvičové konstelaci je operacionalizace role rodiče, která je definována jako přitomnost závislých děti ve věku 17 let a méně v domácnosti respondenta. Díky této definici je sendvičová konstelace téměř nepř́tomná ve věkové skupině 50 až 59 let, která je ale stále ekonomicky aktivní a zároveň v ní každý čtvrtý respondent deklaruje roli pečovatele. Při jiné operacionalizaci role rodiče anebo prarodiče, která by mohla vycházet z poskytované podpory vlastním dětem, by podíl lidí v sendvičové konstelaci ve věku 50 až 59 let výrazně narostl.

Posledním limitem deskriptivních statistik sendvičové konstelace, které tento text nabízí, je průřezový pohled na svět skrze data. $4 \%$ respondentů se nacházela v sendvičové konstelaci v době dotazování. Kdybychom se dotazovali na souběh rolí například za posledních 10 let, opět bychom získali vyšší podíl lidí nacházejících se v sendvičové konstelaci.

Dopad na well-being člověka tvořil výzkumné těžiště textu. Při zkoumání vlivu sendvičové konstelace na well-being respondenta jsem se vymezil proti obecné operacionalizaci well-beingu v podobě vágní spokojenosti se životem anebo pocitu štěstí, u kterého jsem nepředpokládal souvislost se sendvičovou konstelací. Na druhou stranu jsem nabídl tři specifikované dimenze well-beingu, ve kterých jsem předpokládal vliv sendvičové konstelace.

Lidé v sendvičové konstelaci častěji zažívají mírný nesoulad mezi pracovní a soukromou sférou, respektive tento nesoulad zažívá o $14 \%$ více respondentů v konstelaci než mimo ni. Tento rozdíl je sice statisticky signifikantní, ovšem na hranici věcné významnosti. Silnější nesoulad zažívali lidé v konstelaci i mimo ni stejnou měrou.

Další mé očekávání bylo spojeno s představou sendvičové konstelace jako situace, která si nejen nárokuje zdroje člověka, ale zároveň je i samotným zdrojem pro člověka. Situace poskytování podpory může být obousměrná a můžeme rozlišovat různé intenzity reciprocity. Předpokládal jsem, že situace s nízkou reciprocitou bude mít negativní dopad na kvalitu vztahu s př́ijemcem podpory, rodičem. Tomuto předpokladu poskytují data podporu. Pokud respondent intenzivněji podporuje své rodiče, roste pozitivní hodnocení vztahu s nimi s tím, jak roste množství pomoci proudící od rodičů $\mathrm{k}$ respondentovi. Vůbec nejčastěji hodnotí vztah s rodiči jako velmi dobrý respondenti, kteří vydatně podporují své rodiče, a tito rodiče vydatně podporují své děti nazpět. V situaci této intenzivní reciprocity hodnotí $70 \%$ respondentů vztah s rodiči jako velmi dobrý.

Třetí dimenzi well-beingu jsem specifikoval jako dopad nízké afektuální solidarity způsobující negativní hodnocení vztahu s př́jemcem péče. Pokud respondent necítí k rodiči blízkost a zároveň nastane (pečovatelská) situace, $\mathrm{v}$ důsledku které bude respondent trávit s tímto 
rodičem množství času, negativně se to promítne do hodnocení vztahu s rodičem. Pro tento předpoklad jsem však nezískal podporu, ba právě naopak. Respondenti s nízkou afektuální solidaritou hodnotí vztah s rodičem jako velmi dobrý téměř dvakrát častěji (38 \% respondentů), když intenzivněji rodiče podporují, oproti situaci, když rodiče podporují málo nebo vůbec $(20 \%)$.

$\mathrm{V}$ rámci tradice výzkumů sendvičové konstelace jsem také pátral po vztahu mezi obecným indikátorem well-beingu, $v$ prrípadě tohoto textu obecným pocitem štěstí, a sendvičovou konstelací. Předpokládal jsem absenci asociace a data tento předpoklad podpořila. Vztah mezi pocitem štěstí a sendvičovou konstelací není věcně ani statisticky významný.

Limity tohoto textu jsou dány dostupností vhodných dat $\mathrm{k}$ analýze. Pro důkladnější porozumění sendvičové konstelaci popř́padě mechanismům rodinné solidarity v souvislosti s péčí o stárnoucí členy rodiny je sekundární analýza průřezových dat nedostatečná. Klíčové informace, které postrádám, se týkají intenzity poskytované podpory rodičům a intenzity poskytované podpory dětem. Žádoucí by byl početnější datový soubor. Ačkoliv data ISSP 2011-2012 disponují 1804 respondenty, $\mathrm{v}$ důsledku kritérií sendvičové konstelace se dostáváme na podsoubor 78 respondentů, který již trpí velkou výběrovou chybou a neumožňuje hlubší spolehlivé analýzy. Pro ověření kauzality implicitně obsažené ve zde testovaných hypotézách jsou nezbytná nejlépe panelová data, nebot' na prưřezových datech nemůžeme ověrit, zda se změna ve well-beingu projevila opravdu až po vystavení člověka sendvičové konstelaci.

Dalším limitem textu je volba jednotlivce poskytujícího péči jako výzkumné jednotky, která je podmíněna zvoleným tématem sendvičové konstelace. Péče se sice může odehrávat $\mathrm{v}$ režii jednotlivce, častějším případem je však péče jako výsledek působení několika lidí. Na péči o člověka s omezenou soběstačností se mohou podílet jeho partner, potomek, vnouče, jiný př́ibuzný, neformální pečovatelka z okruhu rodinných známých, terénní pečovatelská služba, denní či týdenní stacionáŕ. Vhodným př́stupem $\mathrm{k}$ zachycení dopadu pečovatelské role na well-being pečujícího by bylo použít jako výzkumnou jednotku pečovatelskou situaci, $\mathrm{v}$ jejímž středu by stál př́ijemce péče obklopen různými formami poskytování péče. Získali bychom tak vhled do vnitřní dynamiky poskytování péče a formách dopadu na well-being člověka $\mathrm{v}$ závislosti na charakteru pečovatelské konstelace.

Co důležitého tento text přinesl? Víme, jaký díl lidí se nachází v sendvičové konstelaci. 4\% podíl odpovídá př́i použití podobně mírných kritérií konstelace situaci v Německu (Künemund 2006). Pro Česko neplatí přirovnání o ženách uprostřed, nebot' českých žen je v sendvičové konstelaci jen o něco málo více než mužů. $\mathrm{V}$ textu jsem se zaměřil na dopad konstelace na well-being člověka a demonstroval jsem, že než hledat projevy tohoto dopadu v obecném indikátoru well-beingu, je smysluplnější se zaměřit na dílčí dopady ve specifických oblastech života, které jsou teoreticky podloženy. Zajímavým výsledkem je, že sendvičová konstelace nemusí zdroje člověka pouze vyčerpávat, ale také je doplňovat skrze reciprocitu podpory směřující od rodičů zpět $\mathrm{k}$ respondentovi, což jde ruku v ruce s pozitivním hodnocením vztahu k rodičům. 


\section{Literatura}

AGREE, Emily, Beverley BISSETT a Michael S. RENDALL. Simultaneous care for parents and care for children among mid-life British women and men. Population trends, 2003, č. 112, s. 29-35. ISSN 0307-4463.

BENGTSON, Vern L. a Robert EL ROBERTS. Intergenerational solidarity in aging families: An example of formal theory construction. Journal of Marriage and the Family, 1991, roč. 53, č. 4, s. 856-870. ISSN 0022-2445.

BLIESZNER, Rosemary a Jay A. MANCINI. Aging parents and adult children: Research themes in intergenerational relations. Journal of Marriage and the Family, 1989, roč. 51, č. 2, s. 275-290. ISSN 0022-2445.

BRODY, Elaine M. "Women in the middle" and family help to older people. The Gerontologist, 1981, roč. 21, č. 5, s. 471-480. ISSN 0016-9013.

EVANDROU, Maria a Karen GLASER. Changing economic and social roles: the experience of four cohorts of mid-life individuals in Britain, 1985-2000. Population trends, 2002, č. 110, s. 19-30. ISSN 0307-4463.

EVANDROU, Maria a Karen GLASER. Family, work and quality of life: changing economic and social roles through the lifecourse. Ageing and Society [online]. 2004, roč. 24, č. 5, s. 771-791 [cit. 3. 2. 2014]. ISSN 0144-686X, 1469-1779.

GENDER STUDIES. Slad'ováni rodiny a práce, rovné príležitosti u žen v předdůchodovém věku pečujícich o závislého člena rodiny [online]. Gender Studies, (C) 2013 [cit. 2. 2. 2014]. Dostupné z: http:// aa.ecn.cz/img_upload/8b47a03bf445e4c3031ce326c68558ae/zz_pecujici_zeny_fin_080813.pdf.

GRUNDY, Emily a John C. HENRETTA. Between elderly parents and adult children: a new look at the intergenerational care provided by the 'sandwich generation'. Ageing and Society [online]. 2006, roč. 26, č. 5, s. 707-722 [cit. 3. 2. 2014]. ISSN 0144-686X, 1469-1779.

INGERSOLL-DAYTON, Berit, Margaret B. NEAL a Leslie B. HAMMER. Aging Parents Helping Adult Children: The Experience of the Sandwiched Generation. Family Relations, 2001, roč. 50, č. 3, s. 262-271. ISSN 0197-6664.

KÜNEMUND, Harald. Changing welfare states and the „sandwich generation” - increasing burden for the next generation. International Journal of Ageing and Later Life, 2006, roč. 1, č. 2, s. 11-30. ISSN 1652-8670.

LOOMIS, Laura S. a Alan BOOTH. Multigenerational caregiving and well-being: The myth of the beleaguered sandwich generation. Journal of Family Issues, 1995, roč. 16, č. 2, s. 131-148. ISSN 0192-513X.

MARKS, Nadine F. Does it hurt to care? Caregiving, work-family conflict, and midlife well-being. Journal of Marriage and the Family, 1998, roč. 60, č. 4, s. 951-966. ISSN 0022-2445.

MILLER, Dorothy A. The 'sandwich'generation: Adult children of the aging. Social Work, 1981, roč. 26, č. 5, s. 419-423. ISSN 0037-8046.

MOŽNÝ, Ivo. Mezigenerační solidarita: výzkumná zpráva z mezinárodního srovnávacího výzkumu „Hodnota dètí a mezigeneračni solidarita “. Praha: VÚPSV, Výzkumné centrum Brno, 2004. ISBN 8023942794.

SPILLMAN, Brenda C. a Liliana E. PEZZIN. Potential and Active Family Caregivers: Changing Networks and the 'Sandwich Generation'. Milbank Quarterly [online]. 2000, roč. 78, č. 3, s. 347-374 [cit. 3. 2. 2014]. ISSN 1468-0009.

SZYDLIK, Marc. Intergenerational Solidarity and Conflict. Solidaridad y conflictos intergeneracionales, 2008, roč. 39, č. 1, s. 97-114. ISSN 00472328.

VIDOVIĆOVÁ, Lucie a Ladislav RABUŠIC. Senioři a sociálni opatření v oblasti stárnutí v pohledu české veřejnosti. Zpráva z empirického výzkumu [online]. Brno: Výzkumný ústav práce a sociálních věcí, 2003 [cit. 3. 2. 2014]. Dostupné z: http://www.mature-project.eu/materials/vidrab.pdf. 
WHITBECK, Les, Danny R. HOYT a Shirley M. HUCK. Early family relationships, intergenerational solidarity, and support provided to parents by their adult children. Journal of Gerontology, 1994, roč. 49, č. 2, s. 85-94. ISSN 0022-1422.

\section{Autor}

Michal Šindelář je doktorandem Katedry sociologie Fakulty sociálních studií Masarykovy univerzity. Během práce na článku se sám ocitl v téměř sendvičové konstelaci. Pracuje pro Ústav populačních studií a na FSS MU vyučuje práci s Atlas.ti. Více o autorovi na http:// about.me/smichal.

Kontakt: msindela@fss.muni.cz 